\title{
PENGARUH PENAMBAHAN CMC SEBAGAI SENYAWA PENSTABIL TERHADAP YOGHURT TEPUNG GEMBILI
}

\author{
Dewi Cakrawati dan Mochamad Angga Kusumah \\ Program Studi Pendidikan Teknologi Agroindustri, FPTK UPI \\ Korenspondensi : dewicakrawati@upi.edu
}

\begin{abstract}
The study aims to determine the effect of CMC in preventing yoghurt separation in 7 days with the addition of $2 \%$ Dioscorea esculenta flour. Organoleptic test using quality hedonic was conducting to find out yoghurt with addition of CMC that had accepted characteristic by panelists. Research was carried out using regression method to determine the total titrated acid, $\mathrm{pH}$ and separation level of yoghurt during storage. The concentrations of CMC were added at $0.2 \%, 0.4 \%, 0.6 \%, 0.8 \%$. The analysis showed the addition of $0.6 \%$ CMC showed the lowest separation with high viscosity grades of DPAs 40.25. Yoghurt storage for 7 days shows a graph of the $\mathrm{pH}$ value and total titrated acid were parabolic where increasing in total titrated acid value would lower the $\mathrm{pH}$ value. Yoghurt was damaged on the 7th day of storage at room temperature characterized by the increasing in the $\mathrm{pH}$ value and damage to the organoleptics properties, namely yoghurt flavor and aroma.
\end{abstract}

\section{PENDAHULUAN}

Dewasa ini konsumen

mengharapkan memperoleh dua manfaat sekaligus saat mengkonsumsi produk pangan yaitu pemenuhan nutrisi untuk tubuh juga memberikan nilai tambah untuk menjaga dan memelihara kesehatan, dimana produk ini dikenal dengan istilah pangan fungsional (Alsaffar, 2011). Yoghurt merupakan produk olahan susu yang dibuat dengan cara fermentasi menggunakan bakteri Lactobacillus bulgaricus dan Streptococcus thermophilus dengan mengubah laktosa menjadi asam laktat (Robinson and Tamime, 2006). Menurut Robertfroid (2000), bakteri asam laktat bermanfaat bagi tubuh karena menyeimbangkan bakteri dalam usus besar dan mengurangi resiko berkembangnya bakteri merugikan.

Sumber karbon bagi bakteri asam laktat dikenal dengan istilah prebiotik yang menurut O'Hara et al (2007) dapat berupa oligosakarida, seperti inulin dan fruktooligosakarida, juga dapat berupa pati resisten yang terdapat secara alami pada bahan pangan maupun hasil modifikasi pati. Salah satu komoditas hasil pertanian yang mengandung prebiotik adalah umbi gembili, yang menurut penelitian Winarti et al (2011), gembili mengandung inulin sebesar $14,77 \%$.

Gembili merupakan salah satu umbiumbian minor di Indonesia. yang berpotensi untuk dikembangkan sebagai sumber pangan pokok alternatif, karena bagian umbi dari tanaman ini memiliki kandungan karbohidrat yang tinggi. Penelitian Rauf dan Lestari (2009) menunjukkan kandungan karbohidrat pada gembili sebesar $81,40 \%$ sehingga berpotensi dikembangkan sebagai sumber pati. Penambahan tepung gembili pada minuman yoghurt diharapkan dapat meningkatkan kandungan serat pangan berupa inulin pada yoghurt.

Permasalahan dari pati yang diperoleh dari umbi lokal adalah ketidakstabilannya pada suhu tinggi dan kondisi asam, padahal pada proses pembuatan yoghurt digunakan suhu tinggi untuk pasteurisasi susu serta produk akhir yoghurt yang bersifat asam. Modifikasi perlu dilakukan untuk memperbaiki sifat fungsional pati, salah satu caranya adalah dengan modifikasi fisik dengan perlakuan pra pemanasan. 
Penelitian Kartika (2015) menunjukkan yoghurt dengan penambahan $2 \%$ tepung gembili memiliki karakteristik paling diterima panelis. Tetapi permasalahan muncul saat penyimpanan dimana yoghurt akan terpisah menjadi 2 fase sehingga dibutuhkan penambahan penstabil. Penelitian Sawitri, Manab dan Palupi (2008) menunjukkan penggunaan gelatin sebagai penstabil mampu memberikan pengaruh yang nyata terhadap tekstur yoghurt. Salah satu penstabil yang dapat dignakan dalam produk olahan pangan ialah CMC yang merupakan jenis penstabil sintesis ester polimer selulosa yang larut dalam air dibuat dengan mereaksikan natrium monoklorasetat dengan selulosa basa. Penambahan penstabil berfungsi dapat meningkatkan masa simpan yoghurt dengan menekan pertumbuhan bakteri pembusuk (Utomo, Purwadi, dan Thohari, 2013). Maka dari itu penulis ingin mengetahui pengaruh penambahan penstabil dengan menggunakan CMC sebagai penstabilnya terhadap yoghurt yang telah ditambahkan tepung ubi gembil.

Penelitian ini bertujuan untuk mengetahui konsentrasi CMC yang ditambahkan sehingga menghasilkan produk yoghurt terbaik yang disukai panelis serta karakteristik yoghurt dengan penambahan penstabil CMC selama 7 hari yang meliputi sifat fisiko kimia seperti total asam tertitrasi, $\mathrm{pH}$, dan tingginya tingkat pemisahan.

\section{METODE PENELITIAN}

Penelitian ini dilakukan dari bulan Maret 2015 hingga April 2015 bertempat di Laboratorium TPHP dan Laboratorium Pengawasan Mutu Program Studi Pendidikan Teknologi Agroindustri FPTK UPI, Bandung.

Alat yang digunakan terdiri dari alat untuk pembuatan yoghurt (kompor, panci alumunium, termometer, pengaduk, jar, gelas ukur, timbangan), alat untuk analisis terdiri dari $\mathrm{pH}$ meter, buret, viscometer. Bahan yang digunakan yaitu susu sapi, gembili starter yoghurt, $\mathrm{CMC}$ bahan untuk analisis $(\mathrm{NaOH}$, phenophtalen, buffer $\mathrm{pH} 4$ dan buffer $\mathrm{pH} 7$, sodium hidrogen ftalat).

Tahapan penelitian terdiri dari

1. Pembuatan tepung gembili pra masak mengacu pada prosedur yang diajukan Alsuhendar dan Ridawati (2005). Tahapan pembuatan tepung gembili pramasak disajikan pada Gambar 1. 


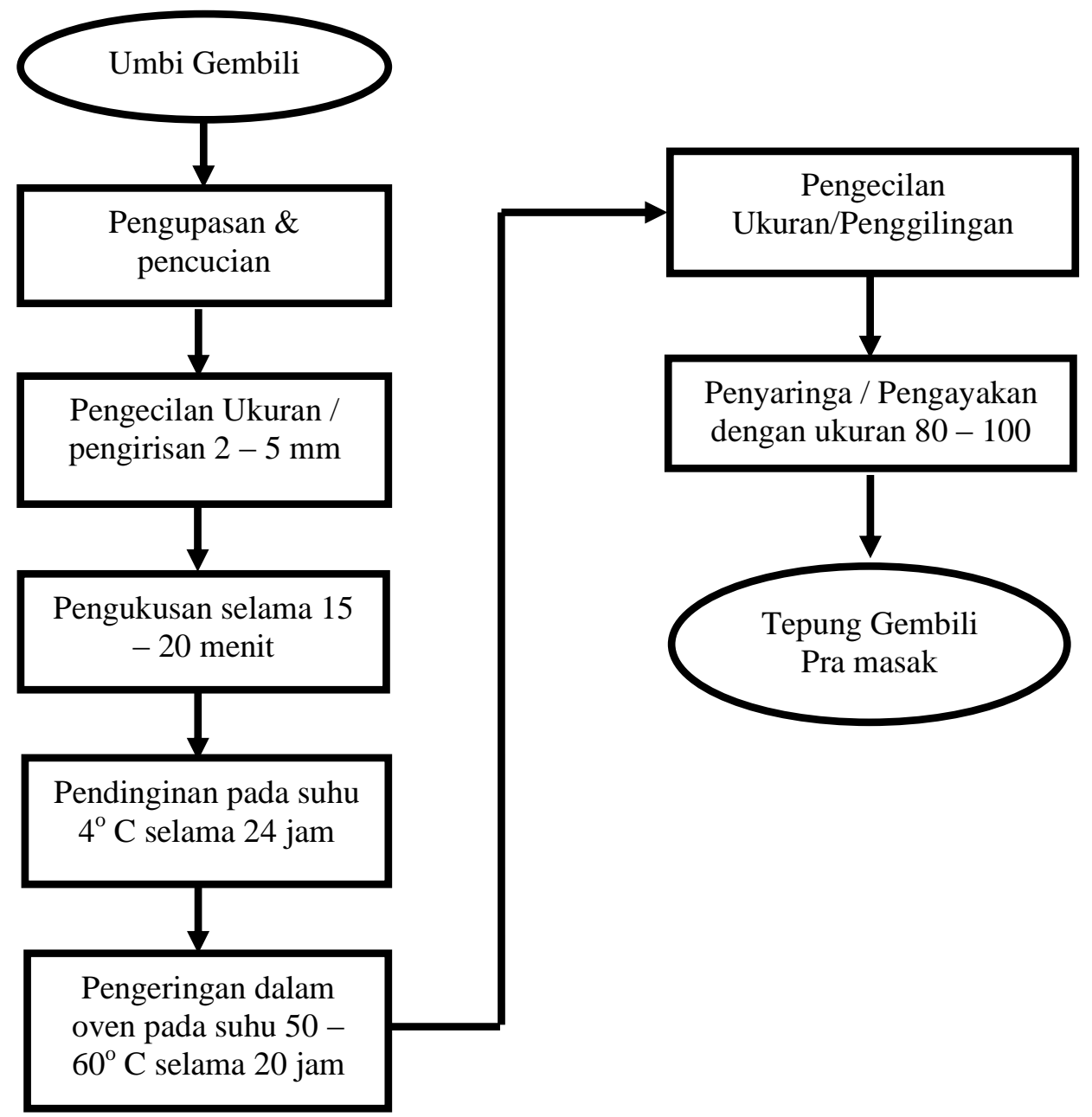

Gambar 1. Diagram alir proses pembuatan tepung gembili pra masak Modifikasi : Alsuhendar dan Ridawati (2005)

2. Pembuatan yoghurt

Pembuatan yoghurt merpakan modifikasi dari prosedur yang diajukan Tamime (2006), dengan starter yoghurt yang ditambahkan sebanyak $5 \%$ dan tepung gembili pra masak sebanyak $2 \%$. Diagram proses pembuatan yoghurt disajikan pada gambar 2.

3. Penyimpanan yoghurt selama 7 hari
Yoghurt yang telah ditambahkan tepung gembili pra masak dan CMC selanjutnya dianalisis secara organoleptik menggunakan uji mutu hedonik dengan panelis agak terlatih disimpan selama 7 hari pada suhu ruang dan dilakukan pengamatan yoghurt meliputi $\mathrm{pH}$ dan total asam tertitrasi serta tingkat pemisahan. 


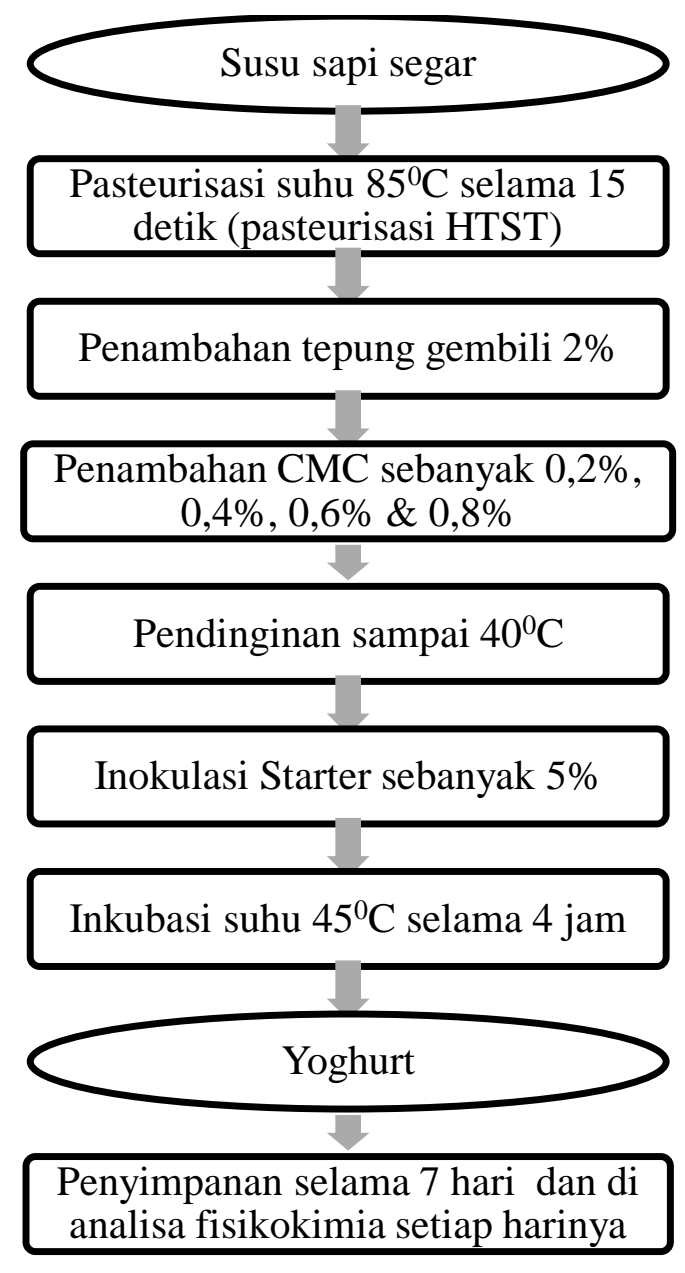

Diagram Proses pembuatan yoghurt drink

Modifikasi Robinson and Tamime (2006)

Rancangan penelitian menggunakan Analisis Regresi Sederhana untuk uji TAT, $\mathrm{pH}$, \& Pemisahan dengan empat perlakuan dan dua ulangan, dengan empat konsentrasi penambahan CMC yang berbeda yaitu pada konsentrasi $0,2 \%, 0,4 \%, 0,6 \%$ dan $0,8 \%$.

\section{Prosedur Analisis}

\section{Pengujian pH}

Sampel dalam wadah diukur $\mathrm{pH}-$ nya dengan menggunakan $\mathrm{pH}$ meter. Terlebih dahulu $\mathrm{pH}$ meter dinyalakan, kemudian elektroda $\mathrm{pH}$-meter dimasukkan dalam buffer pH 4,31 dan 6,86. Sampel ditimbang sebanyak 1 gram, kemudian dilarutkan dalam $10 \mathrm{ml}$ aquades dan dimasukkan ke dalam gelas ukur. Setelah itu elektroda dicelupkan pada larutan sampel dan dibiarkan beberapa saat sampai diperoleh pembacaan yang stabil. Nilai yang diperoleh dari hasil pembacaan pada pH meter sampai angka digital menunjukkan nilai $\mathrm{pH}$ tetap.

\section{Pengujian Total Asam Tertitrasi}

$10 \mathrm{ml}$ susu ditambah 2-3 tetes indikator fenolftalin $1 \%$ kemudian dititrasi menggunakan larutan $\mathrm{NaOH} 0,1 \mathrm{~N}$ sampai titik akhir titrasi tercapai, yaitu terbentuk warna merah muda tetap. Total asam dihitung sebagai persen asam laktat dengan rumus sebagai berikut:

Kadar asam laktat $(\%)=\underline{\text { A x B x 0,009 x } 100}$

$$
\mathrm{C} \times 1000
$$

di mana $\mathrm{A}=\operatorname{ml~NaOH} 0,01 \mathrm{~N}$ 


$$
\mathrm{C}=\text { bobot sampel }
$$

\section{HASIL DAN PEMBAHASAN}

Yoghurt adalah produk fermentasi susu, biasanya susu sapi, dengan mikroorganisme yang digunakan yaitu bakteri asam laktat. Produk akhir yoghurt harus menagndung $1,0 \times 10^{5}$ colony forming units (cfu) (Robinson et al, 2006). Fermentasi mengubah laktosa pada susu menjadi asam laktat yang menyebabkan penuruan $\mathrm{pH}$ yang kemudian menyebabkan denaturasi dan koagulasi protein susu sehingga mempengaruhi tekstur yoghurt (Buckle, 1988). Hutkins (2006) menambahkan susu merupakan bahan baku yang cocok untuk proses fementasi karena mengandung nutrisi seperti laktosa $(5 \%)$, protein $(3,3 \%)$ dengan aktivitas air mendekati 1 dan $\mathrm{pH}$ 6,6-6,7, cocok untuk pertumbuhan mikroorganisme. Yoghurt dapat terbuat dari susu skim (tanpa lemak), susu murni, susu rendah lemak.

Menurut Robinson dan Itsaranuwat (2006), karakteristik organoleptik yoghurt bagi konsumen meliputi warna, flavor dan mouth-feel yang berhubungan dengan dengan karakteristik kimia, fisik dan mikrobiologi. Karakteristik mouthfeel dihasilkan dari kandungan protein dan lemak. Flavor dihasilkan dari gula, asam latat serta kultur yang sesuai.. Menurut Robinson et al, (2006), konsistensi yoghurt juga dipengaruhi oleh penambahan zat lain yang berfungsi sebagai penstabil, seperti gelatin, karboksil metil selulosa, gum, karagenan, pati dan pati modifikasi. Hasil analisis organoleptik yoghurt disajikan pada Tabel 1.

$$
\text { Penambahan }
$$

CMC tidak berpengaruh nyata terhadap warna, rasa dan aroma, tetapi berpengaruh pada tekstur dan kekentalan sehingga mempengaruhi kenampakan keseluruhan. Warna yoghurt dinilai dengan kisaran agak suka sampai suka, hal ini akibat penambahan tepung gembili yang berwarna coklat sehingga menimbulkan warna coklat pada aproduk yoghurt. Penambahan CMC dapat mempengaruhi rasa dan mengurangi bau langu (Tripamungkas, 2015) meskipun pada penelitian ini penambahan CMC tidak memberikan pengaruh signifikan terhadap aroma dan rasa yoghurt. Hasil uji organoleptik menunjukkan panelis paling menerima yoghurt dengan penambahan $0,6 \%$ CMC sementara Tripamungkas (2015) melakukan penelitian minuman sari kacang hijau dan menyatakan bahwa konsentrasi CMC 0,4\% menghasilkan sari kacang hijau dengan karakteristik paling disukai panelis.

Tekstur dan kekentalan yoghurt dipengaruhi oleh penambahan $\mathrm{CMC}$, hal ini karena CMC merupakan jenis penstabil ester polimer selulosa yang larut dalam air sehingga akan mengikat air dalam yoghurt dan meningkatkan tekstur yoghurt (Winarno, 1998). Penambahan CMC juga akan menghambat pemisahan karena air terperangkap dalam struktur senyawa CMC. Hasil analisis viskositas meunjukkan semakin banyak konsentrasi CMC yang ditambahkan maka nilai viskositas akan semakin tinggi. Penambahan penstabil berfungsi dapat meningkatkan masa simpan yoghurt dengan menekan pertumbuhan bakteri pembusuk (Utomo, Purwadi, dan Thohari, 2013). Meskipun demikian, analisis viskositas yoghurt pada hari ke-7 mengalami kerusakan ditandai dengan penurunan viskositas yang berarti penstabil tidak lagi dapat mengikat air serta kemungkinan adanya kontaminasi mikroorganisme pembusuk. Hasil analisis viskositas disajikan pada Tabel 2.

Selanjutnya yoghurt disimpan selama 7 hari pada suhu ruang untuk mengamati tingginya tingkat pemisahan pada yoghurt dengan penambahan CMC. Pengamatan dilakukan pada total asam tertitrasi, $\mathrm{pH}$ dan tingkat pemisahan. Nilai total asam tertiratsi disajikan pada Gambar 1. 
Tabel 1 Hasil Analisis Organoleptik Yoghurt

\begin{tabular}{ccccccc}
\hline $\begin{array}{c}\text { Penambahan } \\
\text { CMC }\end{array}$ & Warna & Aroma & Rasa & Tekstur & Kekentalan & $\begin{array}{c}\text { Kenampakan } \\
\text { Keseluruhan }\end{array}$ \\
\hline $0,2 \%$ & $3,150^{\mathrm{a}}$ & $3,075^{\mathrm{a}}$ & $2,675^{\mathrm{a}}$ & $1,925^{\mathrm{d}}$ & $1,675^{\mathrm{d}}$ & $2,350^{\mathrm{d}}$ \\
$0,4 \%$ & $2,725^{\mathrm{a}}$ & $3,025^{\mathrm{a}}$ & $2,600^{\mathrm{a}}$ & $2,100^{\mathrm{c}}$ & $2,300^{\mathrm{c}}$ & $2,525^{\mathrm{c}}$ \\
$0,6 \%$ & $3,500^{\mathrm{a}}$ & $3,075^{\mathrm{a}}$ & $2,925^{\mathrm{a}}$ & $3,500^{\mathrm{b}}$ & $4,025^{\mathrm{a}}$ & $3,400^{\mathrm{a}}$ \\
$0,8 \%$ & $3,600^{\mathrm{a}}$ & $3,400^{\mathrm{a}}$ & $3,125^{\mathrm{a}}$ & $3,625^{\mathrm{a}}$ & $3,800^{\mathrm{b}}$ & $3,300^{\mathrm{b}}$ \\
\hline
\end{tabular}

Notasi yang berbeda menunjukan beda nyata pada $\alpha=0,05$

Tabel 2. Viskostas Yoghurt Tepung Gembili dengan Penambahan CMC

Hari ke - Konsentrasi Penambahan CMC Viskositas

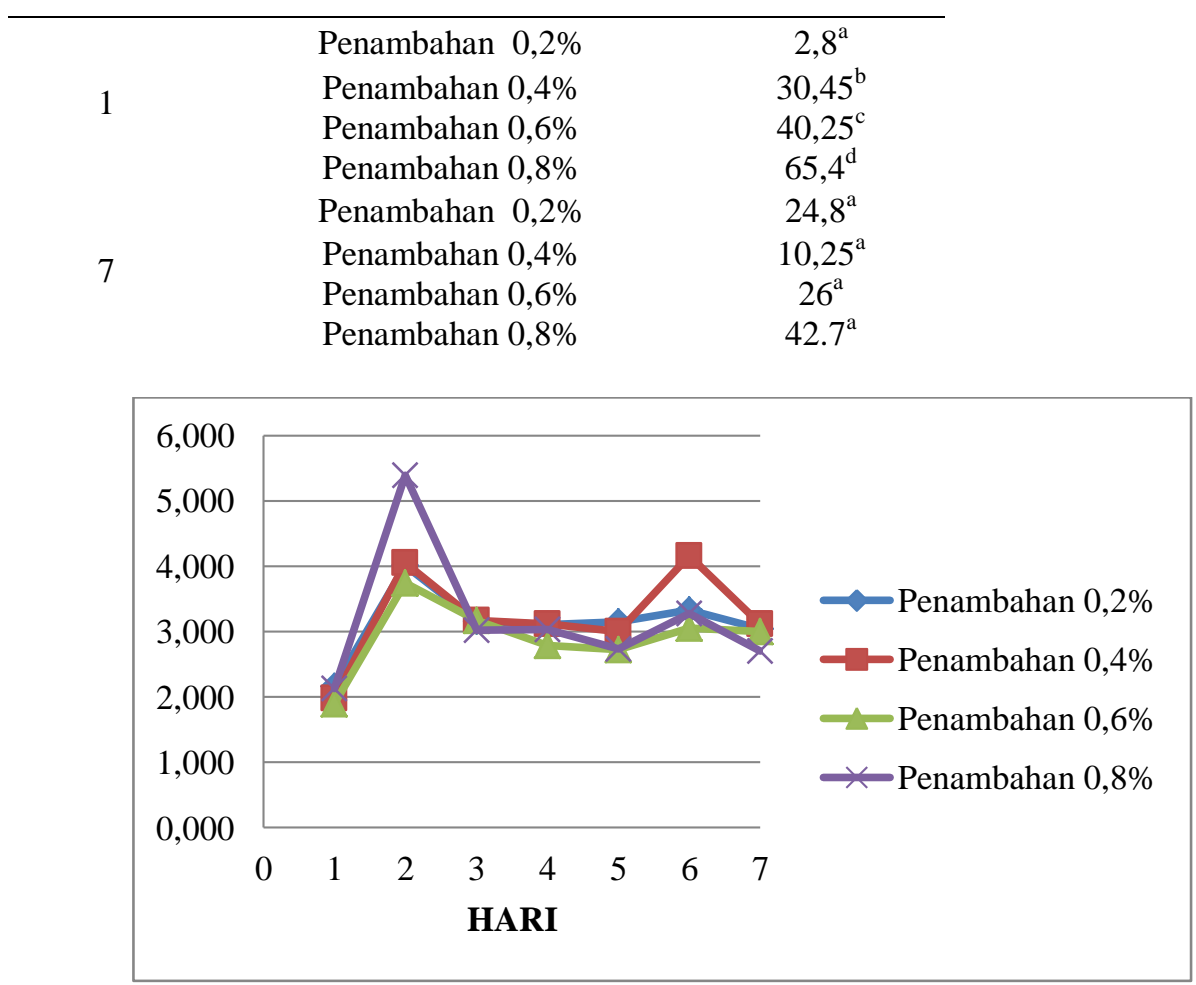

Gambar 1. Grafik Total Asam Tertirasi Selama Penyimpanan

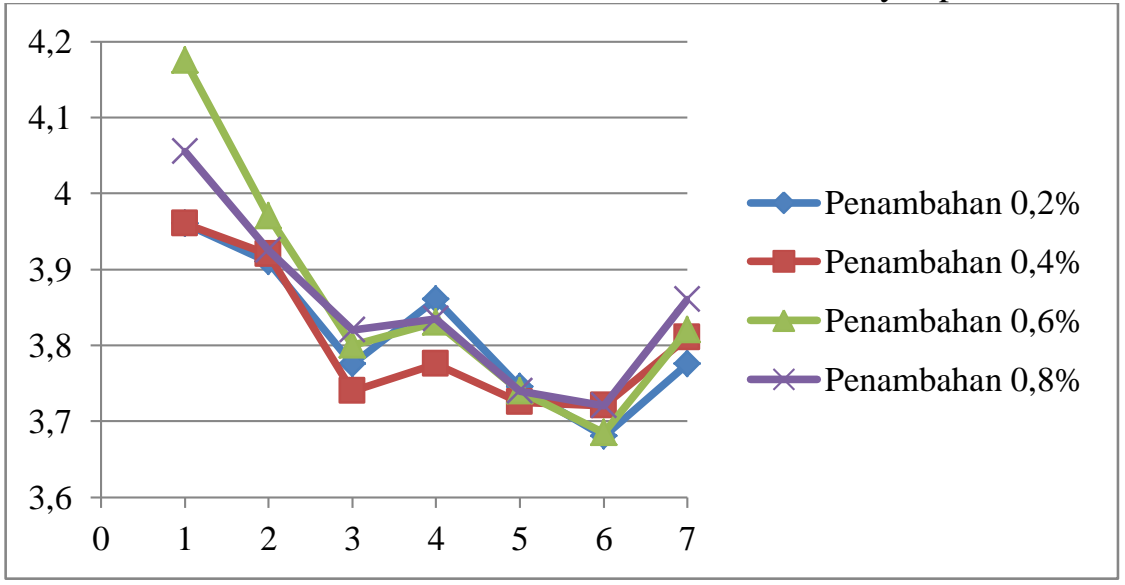

Gambar 2. Grafik Nilai pH Selama Penyimpanan 
Analisis kadar total asam tertirasi pada yoghurt dianggap sebagai asam laktat. Gambar 1 menunjukkan kandungan total asam tertirasi mengalami kenaikan pada hari ke-2. Hal ini sesuai dengan kurva pertumbuhan bakteri asam laktat yang pada hari kedua akan mengalami fase log dimana bakteri akan membelah diri sebanyak $2^{\mathrm{n}}$. Selanjutnya produksi asam laktat mengalami penurunan, hal ini diduga karena penurunan laju pertumbhan bakteri karena mulai menipisnya sumber makanan. Selanjutkan pada hari ke-5 total asam tertirasi kembali meningkat, hal ini diduga karena sudah mulai terjadi kerusakan pada yoghurt sehingga total asam yang terukur tidak hanya asam laktat tetapi juga asam asetat yang merupakan hasil metabolisme mikroorganisme pembusuk.

Nilai $\mathrm{pH}$ yoghurt selama penyimpanan disajikan pada Gambar 2 . Nilai pH yoghurt mengalami penurunan sampai hari ketiga, hal ini sesuai dengan kenaikan nilai total asam tertitrasi. Menurut Winano (1998), CMC memiliki sifat merekatkan komponen pada sampel, membentuk gel pada sampel sehingga mengakibatkan penurunan $\mathrm{pH}$ melambat apabila CMC ditambahkan pada sampel yoghurt dengan kadar yang tinggi, begitupun sebaliknya karena CMC juga dapat menjaga kestabilan $\mathrm{pH}$ pada sampel. Pada hari keempat terdapat kenaikan $\mathrm{pH}$ akibat berakhirnya fase pertumbuhan bakteri. Merujuk pada penelitian Sugiarto (1997), apabila penyimpanan yoghurt pada suhu ruang maka daya tahan yoghurt tersebut hanya 3 hari, dan hari keempatnya dapat dikatakan sampel telah mengalami kerusakan dan berakhirnya fase pertumbuhan bakteri. Namun pada hari keenam hasil pengujian $\mathrm{pH}$ kembali menunjukan penurunan, sama halnya pada hasil pengujian TAT kembali meningkat, dikarenakan adanya bakteri jenis lain yang sudah mengkontaminasi seiring dengan rusaknya produk, diantaranya muncul khamir dan kapang.

Tingginya fase pemisahan selama penyimpanan disajikan pada Gambar 3 . Penambahan CMC 0,2\% menghasilkan tingkat pemisahan paling tinggi, hal ini karena CMC yang ditambahkan tidak cukup untuk mengikat air. Sedangkan penambahan CMC $0,8 \%$ menyebabkan yoghurt sangat kental dan tidak dapat mengalir. Menurut Kowara (2005), penambahan penstabil yang sesuai dan dapat menghasilkan yoghurt yang baik ialah sebnyak 0,5 \% - 0,7\%. Penambahan CMC sebesar 0,6\% mampu mengikat air sehingga yoghurt tidak memisah menjadi 2 fase, hal ini dapat ditunjang dengan penyimpana yoghurt pada suhu rendah sehingga menghambat laju pertumbhan bakteri dan mencegah kontaminasi bakteri pembusuk.

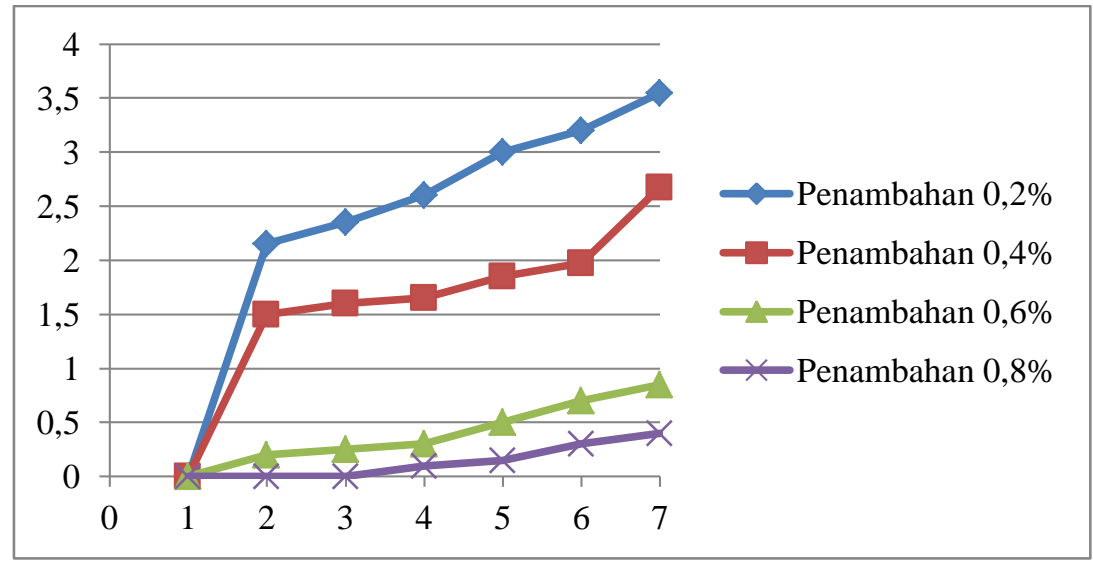

Gambar 3. Tinggi Tingkat Pemisahan Yoghurt selama Penyimpanan 


\section{KESIMPULAN DAN SARAN}

Kesimpulan :

Hasil uji mutu hedonik pada minuman yoghurt gembili dengan penambahan $\mathrm{cmc}$ sebagai penstabil didapat bahwa untuk penambahan CMC sebanyak $0,6 \%$ merupakan sampel yang paling diterima panelis. Penyimpanan yoghurt selama 7 hari menunjukkan nilai TAT dan nilai $\mathrm{pH}$ berbanding terbalik, sedangkan penambahan CMC 0,8\% menyebabkan yoghurt memiliki tingkat pemisahan paling rendah.

\section{Saran}

Sebaiknya digunakan penstabil lain untuk mengetahui pengaruhnya terhadap kestabilan yoghurt. Sebaiknya dilakukan penyimpanan yoghurt pada suhu rendah untuk mengetahui pengaruhnya terhadap umur simpan dan kualitas yoghurt.

\section{DAFTAR PUSTAKA}

Alsuhendra. Ridawati. 2005. Pengaruh Modifikasi secara Pregelatinisasi, Asam dan Enzimatis terhadap sifat fungsional tepung umbi gembili (Dioscorea esculenta). Artikel Ilmiah. Universitas Negeri Jakarta. (on-line) http//www.pdf-archieve.com (diunduh tanggal 26 Juli 2011)

Alsaffar, AA. 2011. Effect of food processing on the resistant starch content of cereal dan cereal product- a review. International journal of food science and technology $46 \mathrm{pp}$. 455-462.

Buckle, KA, et al. 1986. Ilmu Pangan. Penerjemah : Hari Purnomo dan Adiono, UI Press, Jakarta.

Hutkins, RW. 2006. Microbiology and Technology of Fermented Foods. Blackwell Publishing, Iowa, USA.

Kartika. 2015. Pengaruh Perbandingan Kultur Campuran Terhadap Karakteristik Yoghurt probiotik Dengan Penambahan Tepung Gembili Modifikasi Fosforilasi. Laporan Proyek Akhir Jurusan Pendidikan Teknologi
Agroindustri. Universitas Pendidikan Indonesia.

Koswara M.Si.,Ir. Sutrisno. 2009. Teknologi Pembuatan Yoghurt. eBookPangan.com

O'Hara, AM. J Keohane, F Shanahan. 2007. Probiotics, Prebiotics and Inflammatory Bowel Disease. In Maria Saarela (ed). Functional Dairy Products. [p 90-117]. Woodgead Publishing Company, Boca Raton, USA.

Polatu, Anissa. 2011. Pengaruh Variasi Kadar Susu Skim Terhadap Kualitas Yoghurt Ubi Jalar Ungu. [Skiripsi] Program Studi Biologi, Fakultas Teknobiologi. Universitas Atmajaya Yogyakarta.

Prabandari,Wuri. 2011. Pengaruh Penambahan Berbagai Jenis Bahan Penstabil Terhadap Karakteristik Fisikokimia dan Organoleptik Yoghurt Jagung. Skripsi pada Jurusan Teknologi Hasil Pertanian Universitas Sebelas Maret. Surakarta.

Rauf, A.W.,M.S Lestari. 2009. Pemanfaatan Komoditas Pangan Lokal Sebagai Sumber Pangan Alternatif di Papua. Jurnal Litbang Pertanian 28 (2) 2009: 54-62. (on-line) http//www.pustakalitbang.go.id (diunduh tanggal 21 Juli 2012)

Roberfroid M.B. 2000 : Prebiotics and probiotics: are they functional foods? Am J Clin Nutr

2000 Jun : 71(6 Suppl):1682S-7S

Robinson, RK., JA Lucey. AY Tamime. 2006. Manufacture of Yoghurt. In Tamime A. (Ed) Fermented Milk [P.53-71] . Blackwell Science, LTD., Oxford.

Robinson, RK., P. Itsaranuwat. 2006. Properties of Yoghurt dan Their Appraisal. In Tamime A. (Ed) Fermented Milk [P.53-71] . Blackwell Science, LTD., Oxford.

Sawitri,M.E.,A.Manab.,T.W.L,Palupi.2008. Kajian Penambahan Gelatin terhadap Keasaman, pH, Daya ikat air dan Sineresis Yoghurt. Jurnal Ilmu dan Teknologi Hasil Ternak, Februari 2008, Hal 35-42.ISSN : 1978-0303. Vol 3, No.1

Sumardikan. 2007. Penggunaan Carboxymethylcellulose (CMC) terhadap pH, Keasaman, Viskositas, 
Sineresis dan Mutu Organoleptik.

Teknologi peternakan: Malang.

Tripamungkas, A. $2015 . \quad$ Pengaruh

Penambahan Carboxy Methylcellulose

(Cmc) Terhadap Sifat Dan Kesukaan

Minuman Sari Kacang Hijau

(Phaseolus radiatus L) available on line

at http//www.etd.ugm.ac.id (diakses

tanggal 30 September 2016)

Utomo,M.S.,Purwadi, dan I.Thohari. 2013.

Pengaruh Tepung Porang

(Amorphophallus Oncophyllus)

Terhadap Kualitas Ypghurt Drink

Selama Penyimpanan Pada

Refrigerator Ditinjau Dari TPC,

Viskositas, Sineresis dan $p H$. Jurnal

Ilmu - Ilmu Peternakan. Vol 23, No 2 (2013).

Winarno, F.G. 2002. Kimia Pangan dan Gizi. PT. Gramedia Pustaka UTama. Jakarta

Winarti, S. E. Harmayani, R. Nurismanto. 2011. Karakteristik Dan Profil Inulin Beberapa Jenis Uwi (Dioscorea spp.). Jurnal Agritech Vol. 31 no. 4 (on-line) http//www.jurnal-

agritech.tp.ugm.ac.id(diunduh tanggal 18 Januari 2013)

Yuniar, D.P. 2010. Karakterisitk beberapa umbi uwi (Dioscorea spp) dan Kajian Potensi Kadar Inulin. Skripsi. Program Studi Teknologi Pangan. Fakultas Teknologi Industri. Universitas Pembangunan Nasional "Veteran" Surabaya. Tidak Diterbitkan 